\title{
Isolation and Characterization of Bacteria and
} Fungi Associated With Biodegradation of Municipal Solid Wastes in Abakaliki Metropolis,
Nigeria

\author{
Ugwu Emmanuel, Iroha Ifeanyichukwu, Ejikeugwu Chika, Onochie Chike, Nwachi \\ Chinyere
}

Department of Applied Microbiology, Faculty of Sciences, Ebonyi State University, Abakaliki, P.M.B 053, Ebonyi State, Nigeria

\begin{abstract}
Microorganisms involved in the biodegradation of municipal solid waste (MSW) in Abakaliki dumps were isolated and characterized using standard microbiology technique. Five municipal solid waste dumpsites located within Abakaliki metropolis, Ebonyi State, Nigeria were used for this study. The potential of individual microbial isolate to grow on the MSW was also studied using nutrient broth supplemented with mineral salt media and thereafter five of the best microbial degraders were subjected to a 98 days biodegradation studies using weight loss, change in pH, density change and $\mathrm{CO}_{2}$ evolution as indices of success. The study showed that different dumpsites had different temperature readings, bacterial and fungal load, caused by the volume of waste dumped and the habits of the inhabitants. The bacteria population isolated from the dumpsites included Pseudomonas spp, Bacillus spp, Lactobacillus spp, Streptococcus spp, Staphylococcus spp and Micrococcus spp. Penicillum spp, Mucor spp, Aspergillus spp, Fusarum spp, Saccharomyces spp and Candida spp were the fungal species isolated from the dumpsites. The bacteria with the highest growth rate were Bacillus spp, Pseudomonas spp, while Aspergillus spp, Mucor spp, and Saccharomyces spp recorded the highest growth rate for the fungi isolates. The fungi group proved to be better microbial degraders than the bacteria population as a percent weight loss of $1.11 \pm 0.03,1.04 \pm$ 0.05 and $1.23 \pm 0.02$ were achieved by Saccharomyces spp, Mucor spp and Aspergillus spp respectively. This was in comparison to the bacteria group, which recorded $0.89 \pm$ 0.04 and $0.87 \pm 0.03$ percent weight loss by Pseudomonas spp and Bacillus spp. Increases in $\mathrm{CO}_{2}$ evolution was equally recorded by both the fungal and bacterial groups as well as increase in acidity. There was a positive correlation
\end{abstract}

among $\mathrm{CO}_{2}$ evolution, weight loss and density for all the test organisms. However, there was no relationship between pH and $\mathrm{CO}_{2}$ evolution, weight loss and density.

Keywords - Municipal Solid Waste, Landfill, Microbial Biodegradation, Abakaliki, Nigeria.

\section{INTRODUCTION}

Wastes are substances produced in our daily (consumption, recreational, production and living) activities, which are unwanted and are no longer useful to us. They are those materials, which are generated as a result of normal operations over which we have control in terms of their production, disposal or discharge [1]. The problem of waste management is rapidly assuming enormous proportions, and it is a problem intensified by our "throwaway" society [2]. Waste if not properly treated and handled, not only threatens human life in the short term, but the environment as a whole in the long run [3]. Some of the common waste disposal techniques in some countries such as waste dumps, landfills and incinerator have proved inadequate [4], and this has contributed to the pollution of the environment. Waste disposal is one of the major problems being faced by all the nations across the globe and that is why it is everyone's business since it is produced on a daily basis [5]. The problems we now face as per municipal waste disposal is fundamentally one of proper waste management. Thus, waste has to be managed for possible reuse, and not just disposed of. Municipal solid wastes generally can be classified in terms of three major sources of generation residential, commercial, and industrial. Sometimes institutional sources are separated from commercial sources and thus a fourth source is referred to as institutional [2]. In the traditional scheme of classification, residential 
(domestic) solid waste consists of household garbage and rubbish, or refuses [2]. In proper waste management procedures, waste is mainly disposed through land filling, composting incineration and recycling processes amongst other procedures. Waste management in developing countries is usually equated with land disposal or discharge into bodies of water [6]. This method of waste management is unscientific and causes nuisance to the public. Microbial degradation involves chemical transformations mediated by soil microorganism during which they satisfy their growth and energy requirements, and detoxify their immediate environment in the process [7]. Soil microorganism specifically fungi and bacteria are known to colonies the waste, carrying out degradation and transformation of biodegradable (organic) materials in the waste [8]. Abakaliki metropolis is lacking in properly managed sanitary landfills and its solid wastes are not treated prior to disposing. The metropolis still indulges in the rudimentary form of waste management that involves the collection and dumping of wastes in various dumpsites scattered in the metropolis particularly in abandoned pit. The improper disposal of untreated solid wastes is not only harmful to human health but also constitute a threat to ecological environment [5]. It is in view of this that this present study, evaluated the microbial degradation potential of some fungi and bacteria associated with municipal solid waste (MSW) in Abakaliki metropolis, Nigeria.

\section{MATERIALS AND METHODS}

Sources and Collection of Municipal Solid Waste (MSW): The MSW sample used in this study were aseptically collected from five different dumpsites located within the Abakaliki municipality; and these dumpsites were designated as dump sites A, B, C, D and E. During the collection of samples from the respective dumpsites, the surface debris at each sampling point were carefully removed with a sterilized trowel and the subsurface scooped at a depth of $10 \mathrm{~cm}$ with another sterilized trowel. The waste samples were transferred into sterile conical flasks, labelled and transported to the Microbiology Laboratory Unit of Ebonyi State University, Abakaliki for microbial analysis.

Treatment of MSW Samples: Prior to microbial analysis, the MSW samples were measured out and air-dried before segregation. Thereafter, the samples were sorted out to remove non degradable components (such as stones, bottles, plastics) and the resultant biodegradable waste was aseptically milled using mortar and sieved with $0.5 \mathrm{~m}^{2}$ wire mesh. The milled MSW was stored in airtight containers for microbiological, biodegradation and physiochemical studies $[9,10]$.

Estimation of densities of heterotrophic bacteria in the MSW: The isolation of bacteria from the MSW was carried out using the pour plate method [10]. Ten (10) g of the MSW sample was placed into a sterile saline in a conical flask, and serial dilution was carried out by pipetting out 10 $\mathrm{ml}$ into sterile $100 \mathrm{ml}$ of the diluents up to $10^{6}$. From the different dilutions $1 \mathrm{ml}$ was taken and inoculated into a sterile Petri dish, and $20 \mathrm{ml}$ of sterile nutrient agar (Oxoid, UK) was then poured, and the plate was swirled and allowed to gel. It was then incubated at $35^{\circ} \mathrm{C}$ for 2 days. Bacterial counts were made from the plates with 30-300 colonies. The calculation of total number of bacteria was done by multiplying the no of colonies by the dilution factor.

Estimation of densities of fungi in MSW: Fungi isolation from the MSW was carried out using the pour plate method [10]. Ten (10) g of the MSW sample was introduced into a sterile conical flask containing $100 \mathrm{ml}$ of sterile saline and serial dilutions was carried out to $10^{5}$ dilutions. From the different dilutions, $1 \mathrm{ml}$ was taken and inoculated into a sterile Petri dish, and $20 \mathrm{ml}$ of sterile Sabouraud dextrose agar (SDA) was then poured, and the plates was swirled and allowed to gel. Incubation was carried out at $35^{\circ} \mathrm{C}$ for 72 hours; and fungal counts were made from the plate.

Identification of Bacteria and fungi Isolated from MSW: The isolated bacteria and fungi were identified based on their cultural and morphological characteristics of their colonies on culture media, and biochemical identification techniques were also employed in the identification of the organisms based on standard microbiological identification techniques $[11,12,13]$.

Determination of MSW utilization potential of the microbial isolates: The ability of the microorganisms isolated from MSW to effectively utilize the MSW as their source of carbon and energy was determined on mineral salt medium (MSM) using the method of Okpokwasili and Okorie [14] and Itah and Essien [15]. Ten (10) $\mathrm{ml}$ of the MSM were dispensed into sterile test tubes and $0.2 \mathrm{~g}$ of the MSW was added to make a MSM-MSW medium that was sterilized by autoclaving. Thereafter, $0.1 \mathrm{ml}$ of nutrient broth cultures of the bacteria isolates was inoculated into the MSM-MSW medium and incubated at $35^{\circ} \mathrm{C}$ for 3 days; and $0.5 \mathrm{~g}$ of the wet weight of mycelium of the fungi were inoculated on the MSM-MSW medium and incubation was done at $35^{\circ} \mathrm{C}$. The biomass of moulds in MSM-MSW medium was determined after 5 days incubation by cultural and analytical techniques as indices of their ability to utilize 
MSW for growth. Bacteria and yeast growth were determined by viable cell counts on Bacto Nutrient agar and Sabourand dextrose agar respectively using the standard spread plate technique [10]. Using the densities derived from viable counts the number of generation (n), generation time (Gt) and growth rate $(\mathrm{Gr})$ of the microbial load were calculated as follows-

Number of generation $(\mathbf{n})=\log b-\log B / \log 2$

Where: $\mathrm{B}=$ bacterial count at zero time, $\mathrm{b}=$ bacterial count at the end of given period of time, $\log =$ Logarithmic to the base 10 .

Generation time (Gt) is equal to $t$ (time which elapsed between $\mathrm{b}$ and $\mathrm{B}$ ) divided by the number of generation (n)

$$
\mathrm{Gt}=\mathrm{t} / \mathrm{n}
$$

The growth rate $(\mathrm{Gr})$ was estimated using the formular: $\mathrm{Gr}$ $=\mathrm{n} / \mathrm{t}$

For the fungi, the percentage increase in weight was calculated using the formular:

Final weight - initial weight $X \quad 100$

Initial weight

Biodegradation studies: Microbial isolates with high percentage growth rate were seeded on MSW as follows:

i. $\quad$ MSW - comprising of $4 \mathrm{ml}$ of Bacillus sp

ii. $\quad \mathrm{MSW}$ - comprising of $4 \mathrm{ml}$ of Pseudomonas sp

iii. MSW- comprising of $4 \mathrm{~g}$ of Aspergillus $\mathrm{sp}$

iv $\quad$ MSW $-4 \mathrm{ml}$ of Saccharomyces Sp.

v. $\quad$ MSW - comprising $4 \mathrm{~g}$ Mucor $\mathrm{sp}$

To test for the ability of the bacteria and fungi group to degrade MSW, the 5 groups were inoculated onto $100 \mathrm{~g}$ of MSW at room temperature $\left(28 \pm 2{ }^{0} \mathrm{C}\right)$ in a submerged culture test system [16], and plastic vials containing $1 \mathrm{~g}$ $\mathrm{BaO}_{2}$ in $10 \mathrm{ml}$ water were introduced into each microcosm to absorb the liberated $\mathrm{CO}_{2}$. The flasks (Microcosms) were incubated at $28 \pm 2^{\circ} \mathrm{C}$ on a rotatory shaker $(150 \mathrm{rpm})$ for 98 days.

Estimation of MSW degradation and viable plate count: The degree of degradation of MSW were measured in four ways by first determining the microbial growth; and secondly by estimating the total mineralization that would be the sum of $\mathrm{CO}_{2}$ evolved from each culture every 3 days during 98 days of incubation; and thirdly, by determining the changes in the levels of chemical attributes of the degrading MSW using $\mathrm{pH}$. The fourth approach was the determination of weight loss. MSW growth was determined by viable cell counts on Bacto nutrient agar and Sabouraud dextrose agar respectively using the standard spread plate technique [10].
Determination of $\mathrm{CO}_{2}$ evolution: The $\mathrm{CO}_{2}$ liberated by the microbial isolates during growth on MSW were determined titrimetrically [17]. The vial contents $\left(\mathrm{BaCO}_{3}\right.$ and $\left.\mathrm{BaOH}\right)$ was washed with $40 \mathrm{ml}$ of distilled water into $250 \mathrm{ml}$ capacity conical flask and the residual $\mathrm{Ba}(\mathrm{OH})_{2}$ titrated with $\mathrm{HCl}$ using phenolphthalein indicator. The $\mathrm{CO}_{2}$ liberated was calculated by the Stotzky's formular: (B-V) NE.

$\begin{array}{cll}\mathrm{V} & = & \text { Volume of acid used in titration } \\ \text { of test sample } & & \\ \mathrm{N} & = & \text { Normality of the acid used } \\ \mathrm{E} & = & \text { Equivalent weight of the acid }\end{array}$

pH: $\mathrm{pH}$ determination was carried out according to the method of Udo and Ogunwale (1986). The $\mathrm{pH}$ was obtained by mixing $20 \mathrm{~g}$ (\% by weight) of the undegraded waste before start of biodegradation process and $50 \mathrm{ml}$ distilled water in a one - liter glass beaker. A calibrated $\mathrm{pH}$ electrode (Kenteil, 7020 Japlin) was used to obtain the $\mathrm{pH}$.

Determination of weight loss in degraded MSW:

The percentage biodegradation rate of MSW was determined from the following relationship:

$\%$ Degradation $=\underline{\mathrm{a}-\mathrm{b}} \times 100$

a

where: $a=$ weight of MSW (initial weight), $b=$ the weight of MSW remaining (final weight).

Data analysis: Comparative and continuous summary descriptive analysis of the data were performed using the statistical package for social sciences (SPSS) version 16.0. The level of significance was maintained at $95 \%$ confidence interval for each test; and the mean, and standard deviation of the degradation indices $\left(\mathrm{CO}_{2}\right.$ evolution, $\mathrm{pH}$, dencity and weight loss) were determined. The correlations among the degradation indices were also estimated using the same statistical software.

\section{RESULTS}

The bacterial and fungal organisms isolated from the municipal solid waste (MSW) used in this study is shown in Table 1. It was observed that the bacterial population isolated from the MSW included Staphylococcus spp, Bacillus spp., Pseudomonas spp., Micrococcus spp., and Lactobacillus spp. However, the fungal populations isolated from the MSW include Aspergillus spp, Mucor spp, Fusarum spp, Penicillum spp, Saccharonmyces spp and Candida spp (Table 1). More bacteria were isolated from the municipal solid wastes than the fungal organisms. Table 
2 shows the monthly temperature reading and the microbial load of the 5 selected dumpsites under study. It was observed that bacterial colony count for the isolated bacteria was in the range of $3.2 \times 10^{2}$ to $3.7 \times 10^{6} \mathrm{cfu} / \mathrm{ml}$. However, colony count for the isolated fungi was in the range of 0.56 $\mathrm{x} 10^{2}$ to $2.2 \times 10^{5}$; and both the isolated fungi and bacteria grew at an average ambient temperature of $30^{\circ} \mathrm{C}$ (Table 2).

Table.1: Bacterial and fungal population isolated from MSW

\begin{tabular}{lll}
\hline Sample & Bacteria & Fungi \\
\hline & & \\
MSW & Staphylococcus spp & Aspergillus spp. \\
MSW & Micrococcus $\mathrm{spp}$ & Penicillium $\mathrm{spp}$. \\
MSW & Bacillus spp. & Mucor spp \\
MSW & Pseudomonas $\mathrm{spp}$ & Fusarum $\mathrm{spp}$ \\
MSW & Lactobacillus $\mathrm{spp}$. & \\
MSW & Streptococcus $\mathrm{spp}$ & \\
& & \\
\hline
\end{tabular}

MSW = Municipal Solid Waste

Table.2: Monthly temperature reading and microbial load of the dumpsites

\begin{tabular}{|c|c|c|c|c|}
\hline Month & Dumpsites & $\operatorname{Temp}^{\circ} \mathrm{C}$ & $\begin{array}{l}\text { Bacterial count } \\
(\mathrm{CFU} / \mathrm{ml})\end{array}$ & $\begin{array}{l}\text { Fungal count (CFU / } \\
\text { ml) }\end{array}$ \\
\hline \multirow[t]{6}{*}{$1^{\text {st }}$ Month } & A & 30 & $3.6 \times 10^{6}$ & $1.2 \times 10^{5}$ \\
\hline & B & 29 & $3.4 \times 10^{6}$ & $1.2 \times 10^{4}$ \\
\hline & $\mathrm{C}$ & 29 & $3.4 \times 10^{4}$ & $0.92 \times 10^{4}$ \\
\hline & $\mathrm{D}$ & 28 & $3.2 \times 10^{2}$ & $0.56 \times 10^{2}$ \\
\hline & $\mathrm{E}$ & 29.5 & $3.6 \times 10^{4}$ & $1.2 \times 10^{5}$ \\
\hline & A & & & \\
\hline \multirow[t]{5}{*}{$2^{\text {nd }}$ month } & & 29.5 & $3.6 \times 10^{6}$ & $1.2 \times 10^{5}$ \\
\hline & B & 29 & $3.4 \times 10^{4}$ & $1.2 \times 10^{4}$ \\
\hline & $\mathrm{C}$ & 28 & $3.2 \times 10^{2}$ & $0.56 \times 10^{2}$ \\
\hline & $\mathrm{D}$ & 30 & $3.6 \times 10^{6}$ & $1.4 \times 10^{5}$ \\
\hline & $\mathrm{E}$ & 29 & $3.4 \times 10^{4}$ & $0.92 \times 10^{4}$ \\
\hline \multirow[t]{5}{*}{$3^{\text {rd }}$ Month } & A & 30 & $3.7 \times 10^{6}$ & $1.5 \times 10^{5}$ \\
\hline & $\mathrm{B}$ & 29.5 & $3.4 \times 10^{5}$ & $1.2 \times 10^{4}$ \\
\hline & $\mathrm{C}$ & 28 & $3.4 \times 10^{2}$ & $0.76 \times 10^{2}$ \\
\hline & $\mathrm{D}$ & 29.5 & $3.4 \times 10^{4}$ & $1.5 \times 10^{4}$ \\
\hline & $\mathrm{E}$ & 30 & $3.6 \times 10^{6}$ & $2.2 \times 10^{5}$ \\
\hline
\end{tabular}

Tables 3, 4, and 5 show the selection of microbial isolates with strong ability to grow on MSW. The ability of the bacteria and fungi isolated from waste dump to grow on the MSW was assessed, and cultures of bacteria with high 
growth rates and high biomass for fungi were also selected.

The growth rate, generation time and number of generations for bacteria were calculated while percentage increase in biomass/weight for fungi was also calculated. Bacillus spp and Pseudomonas spp showed better growth rate while the fungal organisms that showed better growth rate was Aspergillus spp, Mucor spp and Saccharomyces spp (Tables 4 and 5).

Table.3: Assessment of the bacteria species ability to grow on MSW

\begin{tabular}{|c|c|c|c|c|c|}
\hline Isolate & $\begin{array}{l}\text { Initial } \\
\text { bacterial } \\
\text { load (B) }\end{array}$ & $\begin{array}{l}\text { Final } \\
\text { bacteria } \\
\text { load (b) }\end{array}$ & $\begin{array}{l}\text { Number of } \\
\text { generation } \\
\text { (n) }\end{array}$ & $\begin{array}{l}\text { Growth } \\
\text { rate }(\mathrm{Gr})\end{array}$ & $\begin{array}{l}\text { Generation } \\
\text { time (Gt) }\end{array}$ \\
\hline & $\times 10^{4}$ & $\times 10^{6}$ & & & \\
\hline Pseudomonas spp & 3.2 & 6.0 & 7.55 & 9.54 & 0.105 \\
\hline Bacillus spp. & 3.2 & 5.8 & 7.50 & 9.60 & 0.104 \\
\hline Staphylococcus spp. & 3.2 & 4.2 & 7.04 & 10.25 & 0.098 \\
\hline Micrococcus spp. & 3.2 & 3.4 & 6.73 & 10.70 & 0.993 \\
\hline Lactobacillus spp & 3.2 & 4.0 & 6.97 & 10.35 & 0.097 \\
\hline Streptococcus spp & 3.2 & 3.7 & 6.85 & 10.51 & 0.095 \\
\hline
\end{tabular}

Table.4: $\quad$ Assessment of the fungi species ability to grow on MSW

\begin{tabular}{llll} 
Isolate & $\begin{array}{l}\text { Initial } \\
\text { weight }(\mathbf{g})\end{array}$ & $\begin{array}{l}\text { fungal } \\
\text { Cumulative } \\
\text { weight }(\mathbf{g})\end{array}$ & \% Weight increase \\
\hline & $\mathbf{x ~ 1 0 ^ { 3 }}$ & $\mathbf{x ~ 1 0 ^ { 3 }}$ & 82 \\
\hline Aspergillus spp & 0.5 & 0.92 & 14 \\
Penicillum spp. & 0.5 & 0.57 & 6 \\
Fusarum spp & 0.5 & 0.53 & 74 \\
Mucor $\mathrm{spp}$ & 0.5 & 0.87 & \\
\hline
\end{tabular}


Table.5: Assessment of yeast species ability to grow on MSW

\begin{tabular}{|c|c|c|c|c|c|}
\hline Isolate & $\begin{array}{l}\text { Initial Bacterial } \\
\text { Load } \\
\times 10^{3}\end{array}$ & $\begin{array}{l}\text { Final } \\
\text { bacterial } \\
\text { load } \\
x \mathbf{1 0}^{3} \\
\end{array}$ & $\begin{array}{l}\text { Number of } \\
\text { generation } \\
\text { (n) }\end{array}$ & $\begin{array}{l}\text { Growth } \\
\text { rate }(\mathbf{G r})\end{array}$ & $\begin{array}{l}\text { Generation time } \\
\text { (Gt) }\end{array}$ \\
\hline Saccharomyces spp & 2.6 & 4.6 & 0.823 & 145.77 & 0.007 \\
\hline Candida spp. & 2.6 & 3.2 & 0.300 & 400.59 & 0.002 \\
\hline
\end{tabular}

The result of the biodegradation study carried out on the microbial isolates with potential to grow on the MSW is shown in Tables 8-9. The microorganisms isolated from the MSW dump had the ability to degrade the municipal solid waste (MSW) used in this study and which were recovered from the 5 dumpsites. This was shown by the comparative increase in the microbial density, $\mathrm{CO}_{2}$ evolution and loss in weight of the MSW. The increase in microbial cell resulted in increase in the acidity of the waste; and based on the performances of each of the five isolates used for the biodegradation study, the fungi groups performed better than the bacterial group over the test period.

Table.6: Changes in $\mathrm{Co}_{2}$ evolution by the five microbial isolates during biodegradation of MSW

\begin{tabular}{cccccc}
\hline Days & Saccharomyces spp & Mucor spp & $\begin{array}{c}\text { Microorganisms } \\
\text { Aspergillus spp }\end{array}$ & Pseudomonas spp & Bacillus spp \\
\hline 0 & $3.03 \pm 0.02$ & $3.07 \pm 0.05$ & $3.02 \pm 0.01$ & $3.66 \pm 0.05$ & $3.68 \pm 0.05$ \\
14 & $3.07 \pm 0.02$ & $3.20 \pm 0.06$ & $3.15 \pm 0.04$ & $3.79 \pm 0.06$ & $3.80 \pm 0.04$ \\
28 & $3.16 \pm 0.05$ & $3.42 \pm 0.12$ & $3.57 \pm 0.13$ & $3.91 \pm 0.04$ & $3.71 \pm 0.03$ \\
42 & $3.45 \pm 0.11$ & $4.08 \pm 0.47$ & $4.34 \pm 0.17$ & $4.03 \pm 0.05$ & $4.04 \pm 0.11$ \\
56 & $4.42 \pm 0.82$ & $5.68 \pm 0.95$ & $6.59 \pm 0.71$ & $4.24 \pm 0.17$ & $4.52 \pm 0.07$ \\
70 & $6.40 \pm 0.88$ & $8.30 \pm 1.28$ & $8.95 \pm 0.25$ & $4.61 \pm 0.12$ & $4.78 \pm 0.03$ \\
84 & $8.41 \pm 0.87$ & $9.94 \pm 0.13$ & $9.92 \pm 0.17$ & $4.93 \pm 0.15$ & $4.98 \pm 0.04$ \\
98 & $9.66 \pm 0.27$ & $10.21 \pm 0.09$ & $10.26 \pm 08$ & $5.18 \pm 0.05$ & $5.19 \pm 0.10$
\end{tabular}

Values are means \pm standard deviations $\left(\mathrm{cm}^{3} / 100 \mathrm{~g}\right)$

Table.7: Changes in cell density by the 5 microbial isolate during 98 days biodegradation of MSW

Days

\begin{tabular}{|c|c|c|c|c|c|}
\hline & Saccharomyces spp & Mucor spp & Aspergillus spp & Pseudomonas spp & Bacillus spp \\
\hline 0 & $2.905 \pm 0.27$ & $0.50 \pm 0.07$ & $0.45 \pm 0.03$ & $4.70 \pm 0.42$ & $\overline{4.50} \pm 0.31$ \\
\hline 14 & $4.20 \pm 0.78$ & $0.65 \pm 0.06$ & $0.58 \pm 0.03$ & $5.80 \pm 0.52$ & $5.90 \pm 0.31$ \\
\hline
\end{tabular}

Microorganisms 


\begin{tabular}{|c|c|c|c|c|c|}
\hline 28 & $6.00 \pm 0.73$ & $0.84 \pm 0.08$ & $0.81 \pm 0.08$ & $7.00 \pm 0.52$ & $6.70 \pm 0.31$ \\
\hline 42 & $7.30 \pm 0.39$ & $2.41 \pm 1.34$ & $4.28 \pm 1.09$ & $8.20 \pm 0.52$ & $7.60 \pm 0.36$ \\
\hline 56 & $8.10 \pm 0.37$ & $5.36 \pm 1.26$ & $8.35 \pm 0.42$ & $8.90 \pm 0.26$ & $8.19 \pm 0.15$ \\
\hline 70 & $9.10 \pm 0.50$ & $8.28 \pm 1.08$ & $9.25 \pm 0.07$ & $9.30 \pm 0.26$ & $8.40 \pm 0.17$ \\
\hline 84 & $10.10 \pm 0.44$ & $9.73 \pm 0.25$ & $8.71 \pm 0.2$ & $9.70 \pm 0.26$ & $9.20 \pm 0$. \\
\hline 98 & $9.70 \pm 0.68$ & $9.46 \pm 0.41$ & $8.39 \pm 0.17$ & $9.90 \pm 0.22$ & $9.60 \pm 0.21$ \\
\hline
\end{tabular}

Table.8: Changes in ph recorded during 98-day biodegradation of MSW by the 5 microbial isolate

\section{Days}

\begin{tabular}{|c|c|c|c|c|c|}
\hline \multirow[t]{2}{*}{ Days } & \multicolumn{5}{|c|}{ Microorganisms } \\
\hline & Saccharomyces spp & Mucor spp & Aspergillus spp & Pseudomonas spp & Bacillus spp \\
\hline 0 & $6.89 \pm 0.01$ & $6.89 \pm 0.01$ & $6.90 \pm 0.00$ & $6.89 \pm 0.01$ & $6.90 \pm 0.04$ \\
\hline 14 & $6.86 \pm 0.02$ & $6.87 \pm 0.01$ & $6.87 \pm 0.01$ & $6.86 \pm 0.03$ & $6.88 \pm 0.06$ \\
\hline 28 & $6.81 \pm 0.03$ & $6.85 \pm 0.02$ & $6.82 \pm 0.01$ & $6.83 \pm 0.03$ & $6.81 \pm 0.06$ \\
\hline 42 & $6.74 \pm 0.03$ & $6.80 \pm 0.02$ & $6.78 \pm 0.01$ & $6.80 \pm 0.03$ & $6.74 \pm 0.03$ \\
\hline 56 & $6.6 \pm 0.02$ & $6.76 \pm 0.01$ & $6.73 \pm 0.01$ & $6.74 \pm 0.03$ & $6.66 \pm 0.03$ \\
\hline 70 & $6.64 \pm 0.02$ & $6.71 \pm 0.03$ & $6.67 \pm 0.01$ & $6.69 \pm 0.04$ & $6.57 \pm 0.03$ \\
\hline 84 & $6.58 \pm 0.03$ & $6.61 \pm 0.05$ & $6.60 \pm 0.2$ & $6.59 \pm 0.04$ & $6.57 \pm 0.06$ \\
\hline 98 & $6.53 \pm 0.03$ & $6.54 \pm 0.02$ & $6.56 \pm 0.02$ & $6.52 \pm 0.03$ & $6.52 \pm 0.02$ \\
\hline
\end{tabular}

Values are mean \pm Standard deviation

Table.9: Percentage loss in weight recorded for each of the 5 microbial isolate during the 98 days biodegradation study

\begin{tabular}{cccccc}
\hline Days & \multicolumn{5}{c}{ Microorganisms } \\
\hline & Saccharomyces spp & Mucor spp & Aspergilus spp & Pseudomonas spp & Bacillus spp \\
\hline \multirow{2}{*}{0} & $0.23 \pm 0.26$ & $0.10 \pm 0.12$ & $0.00 \pm 0.00$ & $0.04 \pm 0.04$ & $0.03 \pm 0.03$ \\
14 & $0.18 \pm 0.05$ & $0.29 \pm 0.07$ & $0.31 \pm 0.04$ & $0.14 \pm 0.05$ & $0.21 \pm 0.03$ \\
28 & $0.33 \pm 0.08$ & $0.48 \pm 0.08$ & $0.58 \pm 0.02$ & $0.31 \pm 0.09$ & $0.44 \pm 0.003$ \\
42 & $0.51 \pm 0.07$ & $0.65 \pm 0.06$ & $0.68 \pm 0.04$ & $0.49 \pm 0.07$ & $0.55 \pm 0.02$
\end{tabular}




$\begin{array}{cccccc}56 & 0.69 \pm 0.08 & 0.74 \pm 0.03 & 0.82 \pm 0.05 & 0.61 \pm 0.03 & 0.63 \pm 0.06 \\ 70 & 0.86 \pm 0.07 & 0.82 \pm 0.04 & 1.04 \pm 0.04 & 0.71 \pm 0.05 & 0.75 \pm 0.04 \\ 84 & 1.01 \pm 0.06 & 0.92 \pm 0.05 & 1.18 \pm 0.02 & 0.81 \pm 0.03 & 6.57 \pm 0.06 \\ 98 & 1.11 \pm 0.03 & 1.04 \pm 0.05 & 1.23 \pm 0.02 & 0.89 \pm 0.04 & 0.87 \pm 0.03\end{array}$

Values are mean \pm standard deviation (\%)

Tables 10 and 11 show the summary of the relationship between the biodegradation indices recorded by the 5 different microbial isolate and the correlations among the indices. These indices included $\mathrm{CO}_{2}$ evolution, change in $\mathrm{pH}$, microbial density and weight loss. Among the five microbial isolate, there was a positive relationship / correlation between weight loss, $\mathrm{CO}_{2}$ evolution and microbial density. It was also observed that a negative relationship / correlation existed between $\mathrm{pH}$ and other indices $\left(\mathrm{CO}_{2}\right.$ evolution, density and weight loss) in all 5 microbial isolate.

Table.10: The summary of the indices of degradation during the biodegradation of MSW by the five microbial isolates

\begin{tabular}{llcccccc} 
Organisms & \multicolumn{1}{c}{ Indices } & Maximum & N & Mean & Std dev & Sum & Minimum \\
\hline Saccharomyces spp & Carbondioxide & 9,94000 & 32 & 5,18750 & 2,56015 & 166,00000 & 3,00000 \\
& Density & 10,60000 & 32 & 7,17563 & 2,53442 & 229,620000 & 2,60000 \\
& pH & 6,90000 & 32 & 6,71750 & 0,12606 & 214,9600 & 6,50000 \\
& Weight loss & 1,14000 & 32 & 0.61500 & 0.35369 & 19,68000 & 0 \\
Mucor spp & Carbondioxide & 10,32000 & 32 & 5,98750 & 2.95122 & 191,60000 & 3,01000 \\
& Density & 9,9200 & 32 & 4,65375 & 3.91828 & 148.92000 & 0.42000 \\
& pH & 6,90000 & 32 & 6.75375 & 0.12210 & 216.12000 & 6,520000 \\
& Weight loss & 1,10000 & 32 & 0.63000 & 0.31057 & 20.16000 & 0 \\
Pseudomonas spp & Carbondioxide & 5,24000 & 32 & 4.29375 & 0.53592 & 137.40000 & 3.60000 \\
& Density & 10.20000 & 32 & 7.93750 & 1.85451 & 254.00000 & 4.20000 \\
& pH & 6,90000 & 32 & 6.74000 & 0.12794 & 215.6899 & 6.49000 \\
& Weight loss & 0.94000 & 32 & 0.49938 & 0.30129 & 15.98000 & 0 \\
Aspergilus spp & Carbondioxide & 9.3300 & 56 & 5.10286 & 3.80904 & 285.76000 & 0.42000 \\
& Density & 10.35000 & 56 & 6.22554 & 2.94974 & 348.63000 & 3.0100 \\
& pH & 6,90000 & 56 & 6.74143 & 0.11770 & 377.52000 & 6.53000 \\
& Weight loss & 1.25000 & 56 & 0.72982 & 0.40610 & 40.87000 & 0
\end{tabular}


Table.11: Correlations among $\mathrm{CO}_{2}$ evolution, density, $\mathrm{pH}$ and weight loss by the five microbial isolate

\begin{tabular}{|c|c|c|c|c|c|}
\hline Organisms & Indices & $\begin{array}{l}\text { Carbon } \\
\text { dioxide }\end{array}$ & Density & pH & $\begin{array}{l}\text { Weight } \\
\text { loss }\end{array}$ \\
\hline \multirow[t]{4}{*}{ Saccharomyces spp } & Carbondioxide & 1,000 & $\begin{array}{l}0.811 \\
<0.001\end{array}$ & $\begin{array}{l}-0.922 \\
<0001\end{array}$ & $\begin{array}{l}0.912 \\
<.0001\end{array}$ \\
\hline & Density & & 1.000 & $\begin{array}{l}-0.953 \\
<0001\end{array}$ & $\begin{array}{l}<0001 \\
0.917\end{array}$ \\
\hline & $\mathrm{pH}$ & & & 1.000 & $\begin{array}{l}-0.967 \\
<.0001\end{array}$ \\
\hline & Wight loss & & & & 1.000 \\
\hline \multirow[t]{4}{*}{ Mucor spp } & Carbondioxide & 1.000 & $\begin{array}{l}0.985 \\
<0001\end{array}$ & $\begin{array}{l}-0.961 \\
<0001\end{array}$ & $\begin{array}{l}0.877 \\
<0001\end{array}$ \\
\hline & Density & & 1.000 & $\begin{array}{l}-0.937 \\
<0001\end{array}$ & $\begin{array}{l}0.893 \\
<0001\end{array}$ \\
\hline & $\mathrm{PH}$ & & & 1.000 & $\begin{array}{l}-0.917 \\
<0001\end{array}$ \\
\hline & Wight loss & & & & 1.000 \\
\hline \multirow[t]{4}{*}{ Pseudomonas spp } & Carbondioxide & 1.000 & $\begin{array}{l}0.886 \\
<0001\end{array}$ & $\begin{array}{l}-0.992 \\
<0001\end{array}$ & $\begin{array}{l}0.940 \\
<0001\end{array}$ \\
\hline & Density & & 1.000 & $\begin{array}{l}-0.888 \\
<0001\end{array}$ & $\begin{array}{l}0.987 \\
<0001\end{array}$ \\
\hline & $\mathrm{Ph}$ & & & 1.000 & $\begin{array}{l}0.942 \\
<0001\end{array}$ \\
\hline & Weight loss & & & & 1.000 \\
\hline \multirow[t]{4}{*}{ Aspergilus spp } & Carbondioxide & 1.000 & $\begin{array}{l}0.920 \\
<0001\end{array}$ & $\begin{array}{l}-0.893 \\
<0001\end{array}$ & $\begin{array}{l}0.894 \\
<0001\end{array}$ \\
\hline & Density & & 1.000 & $\begin{array}{l}-0.974 \\
<0001\end{array}$ & $\begin{array}{l}0.926 \\
<0001\end{array}$ \\
\hline & $\mathrm{pH}$ & & & 1.000 & $\begin{array}{l}0.967 \\
<0001\end{array}$ \\
\hline & Weight loss & & & & 1.000 \\
\hline \multirow[t]{4}{*}{ Bacillus spp } & Carbondioxide & 1.000 & $\begin{array}{l}0.914 \\
<0001\end{array}$ & $\begin{array}{l}-0.942 \\
<0001\end{array}$ & $\begin{array}{l}0.894 \\
<0001\end{array}$ \\
\hline & Density & & 1.000 & $\begin{array}{l}-0.933 \\
<0001\end{array}$ & $\begin{array}{l}0.905 \\
<0001\end{array}$ \\
\hline & $\mathrm{pH}$ & & & 1.000 & $\begin{array}{l}-0.939 \\
<0001\end{array}$ \\
\hline & Weight loss & & & & 1.000 \\
\hline
\end{tabular}




\section{DISCUSSION}

The results of this study have shown that the different dumpsites have different bacterial and fungal load caused by the volume of waste dumped at these sites; and this goes to show that dumpsites are naturally endowed with diverse species of microbes many of which have weak capability to utilize the components of MSW for growth and proliferation. The MSW degrading profiles of the different microorganisms encountered in the waste is based on their growth rate or percentage increase in biomass/weight. Among the bacterial isolates with strong ability to decompose MSW and utilize it as their sole source of carbon and energy (required for growth) were Pseudomonas spp. and Bacillus spp. while Aspergillus spp. Mucor spp. and Saccharomyces spp were the fungal organisms that utilized the MSW as their sole source of carbon and energy. The implication is that microbes with growth attributes readily colonize MSW. To determine if these microorganisms were really responsible for the biodegradation taking place in a dump, a pilot scale experiment was set up in five different conical flasks; and each was seeded with Bacillus spp, Pseudomonas spp, Aspergillus spp, Mucor spp and Saccharomyces spp. The decomposition abilities of the selected isolates as shown in this study have previously been reported by Obire et al. [18]. The 5 different experiments gave a positive result as they were able to degrade the MSW (under laboratory condition) at room temperature $\left(28 \pm 2^{\circ} \mathrm{C}\right)$. The capability of the microorganisms to degrade the complex MSW substrate was obvious; and this resulted in MSW weight loss, which is an indication of biodegradation [19]. The degree of weight loss was observed to increase with incubation time but also varied between bacterial and fungal organisms. The fungal organisms exhibited higher capability to degrade the MSW and was able to cause $1.23 \% \pm 0.0 .02$ reduction by Aspergillus spp, and $1.04 \pm 0.05$ and $1.11 \pm 0.03$ reduction in weight by Saccharomyces spp and Mucor spp respectively in MSW weight after 98 days of incubation. In contrast, the bacterial organisms caused a $0.89 \pm 0.04$ and $0.87 \% \pm 0.0258$ reduction in weight loss over the same period of incubation for Bacillus spp and Psendomonas spp respectively. However, in most cases, loss in weight as a result of microbial breakdown has always been linked with increase in the activities of the decomposers which is usually indicated by increase in $\mathrm{CO}_{2}$ evolution, thermogenesis and substrate acidity [20]. In this study, the evolution rate of $\mathrm{CO}_{2}$ increased approximately more than one fold over the first 70 days for fungal organisms following MSW mineralization thereafter achieving steady increase. However, the bacterial organisms gave similar though reduced evolution rate until the $84^{\text {th }}$ day when there was a large increase in $\mathrm{CO}_{2}$ evolution rate. The elevated values recorded for fungal species correlate with the degradation potential for MSW; and the MSW degradability was faster with the fungi, and the data shows that degradation with fungi produced more $\mathrm{CO}_{2}$ than bacterial organisms. Previous studies have shown variation in $\mathrm{CO}_{2}$ production from MSW degradation by fungi and bacteria $[20,21,22]$. The $\mathrm{pH}$ of the MSW was affected by the biodegradation process; and the utilization of MSW by the microbes resulted in the growth and concomitant production of acid metabolic products. The acid metabolites are responsible for the decrease in $\mathrm{pH}$ of the MSW, and the acidic level of MSW was remarkably increased by the activities of the fungal organisms. The MSW constituent affected bacterial growth and increase in the acidity of the medium. Increase in acidity of the decomposing MSW was expected and could be ascribed to differences in $\mathrm{pH}$ status of the organic components of the municipal solid wastes. During degradation, the organic acids that have evolved from the process would depress the $\mathrm{pH}$ from the original levels [23,24]. The $\mathrm{pH}$ values obtained in this study are in agreement with the levels reported by Baffa et al. [25] and Deportes et al. [26]. The increase in acidity of degrading substrate would also favour the activity of fungi resulting in the release of simpler nutrient that enhances bacterial proliferation. However, only acid tolerant bacteria species can retain their competitive saprophytic potential in acid medium. Conclusively, the utilization of microorganisms with strong degrading capability for processing MSW would be of great economic and aesthetic value to the environment since most metropolis are littered with MSW without any proper processing for further usage.

\section{REFERENCES}

[1] Odocha, J. N. K (1994). "Waste Generation and Management in a Depressed Economy", A lecture delivered to students of the Law and Environmental Faculties, University of Nigerial Enugu Campus (UNEC) Enugu.

[2] Taiwo, A. A., (2009). Waste Management Towards Sustainable Development in Nigeria. A Case Study of Lagos State. International NGO Journal. 4: 173-179.

[3] Ogwueleka T.Ch (2009). Municipal solid waste characteristics and management in Nigeria. Iran J. Environ Health Sci. Eng, 6(3):173-180. 
[4] Uchegbu, S. N. (2002). Environmental Management and Protection., $2^{\text {nd }}$ Edition Spotlite Publishers, Enugu, Nigeria. PP 39-85.

[5] Ogunji, J.O, Okogwu,O. and Mgbeafuruike J. (2004) Environmental Biology and Waste Management Principles. Ruga Enterprises, Enugu. PP 22 - 28.

[6] Cliinskis, E. and Zaloksnis, D. (1996). Solid waste management in the city of Riga, Latvia: Objective and strategies. Ambio, 25:103-107.

[7] Diaz, U. (ed (2008). Microbial Biodegradation: Genomics and Molecular Biology, $1^{\text {st }}$ Ed. Caister Academic Press. London.

[8] Stainer, R. J.; Ingraham, J. L.; Wheelis, J. and Painter, P. R. (1989). General Microbiology. MacMillian Ed. Ltd, London. PP. 305-314.

[9] Udo, E. J. and Ogunwale CJ. A. (1986). Laboratory Manual for the Analysis of Soil, Plant and Water Samples, $2^{\text {nd }}$ Edition. University Press, Ibadan.

[10] Onyeagba, R. A. (Ed). (2004). Laboratory guide for microbiology 1st Ed. Crystal publisher; Okigwe PP 33 $-87$.

[11] Cheesbrough M (2000). Biochemical tests to identify bacteria. In: District Laboratory Practice in Tropical Countries. $2^{\text {nd }}$ edition. Cambridge University Press, UK. Pp. 178-187.

[12] Malloch, D. (1981). Moulds: Isolation, Cultivation, and Identification. University of Toronto Press, Canada. PP. 1-88.

[13] Barnet, H.L. and Hunter, B. B. (1987) Illustrated General of imperfect fungi. $4^{\text {th }}$ Edition, Macmillan Publishing company, U.S.A.

[14] Okpokwasili, G. C. and Okorie, B. B. (1988). Biodeterioration Potentials of Microorganism Isolated from Car Engine Lubricating oil. Tribology International. 21: 215-220.

[15] Itah, A. Y. and Essien, J. P. (2005). Growth Profile and Hydrocarbonoclastic Potential of Microorganisms Isolated from Tarballs in the Bight of Bonny. World Journal of Microbiology and Biotechnology. 21 (5): 374-385.

[16] Essien, J. P., Akpan, E. J. and Essien, E. P. (2005). Studies on Mould Growth and Biomass Production using Waste Banana Peel. Bioresource Technology, 96: 1451-1456.

[17] Stotzkey, G. (1965). Definition of $\mathrm{CO}_{2}$ In Black, C. A. (ed) Method of Soil Analysis Part 2. Chemical and Microbiological Properties. Madison American Society of Agronomy NY. PP 1-50.
[18] Obire, O.; Nwanbeta, O. and Adue, S. B. N. (2002). Microbial Community of a Waste Dumpsite. Journal of Applied Science and Environmental Management. 6: 78-83.

[19] Warith, M. A. and Sharma, R. (1998). Technical Review of Methods to Enhance Biological Degradation in Sanitary Landfills. Water Qual. Res. $J$. Canada. 33 (3): 417-437.

[20] Tchobanoglous, G.; Theisen, H. and Vigil, S. (1993). Integrated Solid Waste Management: Engineering Principles and Management Issues. Irwin McGrawHill. International Edition San Francisco.

[21] Isinguzo, S. N. and Odi, C. T. I. (1982). Oil Spillage and the use of Mutant Organism for Enhanced Biodegradation. In Nwankwo, J. N.; Ifeadi, C. N.; Odu, C.T. I.; Uchegbu, A.; Ofodile, S. and Ekalu, A. B. (eds). Proceedings of 1987 International Seminar on Petroleum Industry and the Nigerian Environment (pp.133-138). Nigeria National petroleum Corporation, Lagos.

[22] Mandels, M. and Weber, J. (1996). The Production of Cellulose. In: Cellulose and their Applications. Advances in Chemistry Series No. 95, ACS Publication, Washington D. C, PP $391-414$.

[23] Sharma, V. K.; Canditelli, M.; Fontoura, F. and Cornacchia, G. (1997). Processing of Urban and Agroindustrial Residues by Aerobic Composting Review. Energy Conservation., 38: 453-478.

[24] Jahnel, M. C. Melloni, R. and Cardoso, E. J. B. (1999). Maturidade de Composto de Residuo Urbano. Scientia Agricola. 56: 301-304.

[25] Baffa, T., Blanc, M.; Lyon, P. F., Vogt, G.; Marchiani, M.; Fisher, J. L. and Aragno, M. (1996). Isolation of Thermus Strains from hot Compost $\left(60\right.$ to $80^{\circ} \mathrm{C}$ ) Applied Environmental Microbiology. 62: 1723-1727.

[26] Deportes, I. Bendith - Guyond, J. L., Zmiron, O. and Bouvier, M. C. (1998). Microbial Disinfection Capacity of Municipal Solid Waste (MSW) Composting. Journal of Applied Microbiology. 85: 238-246. 